dr. Nives

Ličen

Filozofska

fakulteta $v$

Ljubljani

\title{
Socialni kapital in izobraževalne potrebe v obdobju spreminjanja dela in trga
}

$\mathrm{U}$

čeča se organizacija skrbi za izobraževanje zaposlenih na različnih področjih.

Klasičnim poklicnim izobraževalnim programom, namenjenim strokovnemu izpopolnjevanju, dodajajo programe, ki spodbujajo razvoj zaposlenih na področju komunikacije, medosebnih odnosov, vodenja, refleksivnega pristopa $\mathrm{h}$ karieri in biografiji.

\section{VIDIKI SODOBNEGA RAZVOJA IN SPREMINJANJA DELA}

Vzgoja in izobraževanje sta kompleksen pojav, ki izhaja iz vrednotenja človeka, njegovega dela in pogleda na razvojne možnosti.

Sodobni način življenja zahteva od posameznika številne socialne vloge in temu sledi tudi izobraževanje. V primitivnih kulturah je drugače, te ne poznajo dualizma med čustvi in razumom, pomembnega za vrednotenje, in dualizma med čutenjem in intuicijo, pomembnega za zaznavanje. Zahodna civilizacija je ločila posameznika od družbe, naravo od kulture, znanost od religije (Telban, 2000). Dualizem, kot ga poznamo na Zahodu, nas odda-

Za sodobno identiteto je značilno, da je fluidna, spremenljiva, da se nenehno prilagaja. Identiteta zaposlenega je zelo rahlo opredeljena, ni pravih sidrišč, ampak je le trg, ki določa delo. C̆loveski kapital je cenjen toliko, kolikor prinaša dobička. V »režimu fleksibilnosti nastajajo problemi in z njimi potrebe po izobraževanju na drugačnih poljih kot $v$ obdobju, ki ni bilo označeno kot obdobja tveganja. ljuje od razumevanja življenja kot celote. Ne gre samo za znanost ali religijo, ne samo za poklic ali družino, ne samo za moški ali ženski pol ... Življenje nima samo dveh polov, ima veliko vmesnih stanj.

Zaradi pomanjkljivosti silovitega razvoja so začeli razmišljati o trajnostnem razvoju, ki ga opredeljujejo nekatere skupine dejavnikov. Gosar (1991) jih je opredelil v sedem skupin: delo in gospodarstvo, odnosi, upravne strukture in družbena morala, zdravje in zdravo okolje, način življenja kot izraz kulture v družbi, vzgoja in izobraževanje, mediji. Trajnostni razvoj upošteva vse dejavnike.

Razvoj temelji na sodelovanju med strokami in posamezniki, upoštevaje različne interese posameznikov in skupnosti. Interesi skupnosti in posameznika ne morejo biti zanemarjeni na račun tako imenovanih profitnih ali »podjetniških « interesov. Ekonomija, katere najpomembnejše načelo so materialni interesi, kalkulacije, akumulacija dobička, ni nekaj naravnega $\mathrm{v}$ človeku, je menil Max Weber (1930) in za njim tudi Bourdieu (1998), ki se zavzema za prepoznavanje avtonomije človekove dejavnosti v okviru zgodovinskega procesa in načina življenja.

\section{SOCIALNI KAPITAL}

Civilizacijska kompetenca je bila $v$ devetdesetih letih opredeljena kot sklop pravil, navad in vrednot, ki so predpostavka za participacijo v postmoderni družbi. Gre za kulturne pre- 
dispozicije, ki jih posameznik razvija v povezavi z drugimi. Najpomembnejše pri tem procesu so primarne skupine, ki delujejo na osnovi tesne medsebojne povezanosti, poleg teh pa tudi delovne skupine, druženje $v$ prostem času ipd. Skupaj sestavljajo mrežo socialnega kapitala.

Socialni kapital je razmeroma nov konceptualni pogled na bogastvo odnosov, zato obstaja več različnih opredelitev. Putnam (1993, 2000) ga je opredelil tako: socialni kapital se nanaša na tiste vidike socialne organizacije, kot so zaupanje, norma, omrežja, ki lahko izboljšajo učinkovitost družbe s spodbujanjem koordiniranega delovanja. Bourdieu (1985) pa je opredelil socialni kapital kot gostoto in pogostost ter pomembnost socialnih stikov, ki jih lahko posameznik »mobilizira«, ko jih potrebuje, in se nanje zanese, če želi izboljšati svoj položaj.

Socialni kapital razčlenjujejo $\mathrm{z}$ dveh vidikov. V prvem opazujejo koristi, ki jih ima posameznik od medosebnih odnosov, v drugem pa, kakšne koristi imata skupnost, organizacija ali institucija od socialnega kapitala. Različni avtorji poudarjajo prvi ali drugi vidik. Čedalje bolj pa se strinjajo s tem, da socialni kapital pomeni zmožnost, sposobnost akterjev (posamezniki, skupine, organizacije, gibanja), da si kot deli socialnega omrežja pridobijo korist (Portes, 1998, v: Adam, 2001; 39).

Socialnega kapitala ne moremo meriti, pri presoji smo odvisni od posrednih podatkov. Socialni kapital posredno predstavljajo $\mathrm{s}$ stopnjo zaupanja in vključenostjo, članstvom $\mathrm{v}$ nevladnih organizacijah. Sodeč po teh kazalcih, ugotavlja Adam (2001), da je povprečen Slovenec nezaupljiv, usmerjen individualistično in $\mathrm{v}$ zasebnišvo. Zaupanje se krepi počasi, ne razvije se čez noč. Pri organizaciji izobraževanja se vprašamo, ali lahko vnašamo tuje izobraževalne projekte, ki so jih razvili v kulturi z višjo stopnjo zaupanja, v slovensko kulturno okolje z nizko stopnjo zaupa- nja, ne da bi jih modificirali. Tuji izobraževalni programi ne upoštevajo kulturno-semantičnih posebnosti okolja.

\section{IZOBRAŽEVANJE KOT SPODBUDA ZA RAZVOJ SOCLALNEGA KAPITALA}

Sintagmi človeški kapital in socialni kapital se čedalje pogosteje uporabljata. Ne razmišljamo več o tem, da smo posameznika postavili na raven kapitala.

Osnovna značilnost kapitala je dobiček, ki s svojimi zakenitostmi retrogradno vpliva na vse dejavnosti in odnose do sočloveka in narave, če jih pojmujemo kot kapital. Posameznik je lahko kapital samo v prenesenem pomenu besede. Kapital je figura, ki ponazarja nekaj dragocenega. V sodobnih razpravah ni tako, temveč nasprotno, posameznik je pomemben kot vir dobička. Izobraževanje je le investicija v človeške vire, katere rezultat sta večja zaposlïvost in ekonomski razvoj.

Definicije označujejo kot temeljne sestavine socialnega kapitala zaupanje, sodelovanje/kooperacijo, medsebojno usklajevanje/koordinacijo, participacijo. Kaj je problem? Ljudje se udeležujejo »komunikacijskih treningov«, ki naj bi jih usposobili za drugačne načine medsebojnega sporazumevanja. Pogosto so ti le učenje skriptirane komunikacije, ki jo uporabljajo, kadar si nadenejo maske kooperativnosti, v vsakdanjem življenju pa ne uporabljajo novih vedenjskih vzorcev. Posameznik je prepričljiv v svoji komunikaciji z drugim posameznikom, ko sporoča tisto, o čemer je prepričan. Komunikacijsko usposabljanje je uspešno, kadar posameznik razišče svoje nagibe in kadar najde socialno primerne vzorce za svoja sporočila. Pomembni so je posameznik, njegovo videnje in interpretiranje sveta. Komunikacijski vzorci, ki so le posledica »treninga «, in ne spremembe človeka, niso prepričljivi.

$\mathrm{Na}$ verbalni ravni poudarjamo medsebojno zaupanje, značilnost socialnega kapitala, za- 
Izobraževanje v gospodarstvu in nacionalna strategija izobraževanja odraslih

nemarimo pa tako imenovano institucionalizirano nezaupanje. V okviru države so to mehanizmi kontrole oblasti, $\mathrm{v}$ okviru delovne skupine pa je to pozicija, ki jo imenujejo »dr. $\mathrm{Ne} \ll$. Ta je odgovoren za to, da vedno išče pomanjkljivosti. Zaupanje se razvije takrat, kadar je dovoljeno (ne)zaupati. Zato uspešne koordinacijske skupine ne želijo, da bi se vsi vedno strinjali.

Fukuyama ugotavlja (1995), da je potrebna določena spontana sociabilnost, da se razvije-

\section{Brez socialnega kapitala ni kooperativnega vedenja.} jo možnosti oblikovanja novih skupin ali podjetij na podlagi skupnega interesa in medsebojnega zaupanja. Dolgoročne kooperacije ni mogoče določiti vnaprej. Sodelovanje ne more nastati na osnovi hierarhičnih zapovedi. Pri razvojnih regionalnih projektih ugotavljajo, da niso uspešni, če prebivalci ne sodelujejo pri vseh fazah projekta. Tudi razvojni projekti v podjetjih niso uspešni, če zaposleni le dobijo ukaz, da se morajo obnašati kooperativno. Da podjetje doseže raven spontane sociabilnosti in postane učeče se podjetje, mora skozi več razvojnih faz. Vsaka faza zahteva čas, vendar ga lahko skrajšamo, če izrabimo možnosti izobraževanja.

Če teh zakonitosti ne upoštevamo, se razvije lažna fleksibilnost, ki načne posameznikovo psihofizično ravnovesje.

\section{SKLEPNE MISLI}

Posamezniki so čedalje pomembnejši za razvoj organizacij, zato vse več energije namenjajo neekonomskim vidikom razvoja, kamor spadajo izraba znanja, uporaba inventivnosti, načrtovanje kariere, razvoj odnosne in emocionalne inteligentnosti. Če želi biti organizacija v središču razvoja in ne ostajati v ozadju, si ne sme dovoliti, da bi ga ujela zanka statistične in strukturalne resnice. Pri tem spre- gleda vse tiste dejavnosti, ki so napolnjene s čustvovanjem in gnane $\mathrm{v}$ razvojni spirali s čustvi. Razvijanje čustvene in odnosne inteligentnosti je mnogo več kot razvijanje človeškega in socialnega kapitala $\mathrm{v}$ gospodarski organizaciji, ker seže tudi na druga življenjska področja, v druge socialne vloge. Je izobraževanje, ki ga poleg profitabilnosti označuje tudi »korozija osebnosti « kot posledica novega kapitalizma.

\section{LITERATURA}

Adam, F. in drugi (2001). Sociokulturni dejavniki razvojne uspešnosti. Slovenija v evropski perspektivi. Ljubljana: Znanstveno in publicistično središče.

Bateson, G. (2000). Verso un'ecologia della mente. Milano: Adelphi.

Bourdieu, P. (1985). The Forms of Capital. V: Richarson, J. H.: Handbook of Theory and Research for the Sociologyof Education. New York: Greenwood.

Bronfenbrener, Juri (1997). Ekologija ljudskog razvoja. Beograd: Zavod za udžbenike i nastavna sredstva.

Fukuyama, F. (1995). Trust: The Social Virtues and the Creation of Prosperity. London: Penguin Books.

Gosar, l. (1991). Za usklajeno reševanje razvojnih problemov. V: Barbič, A. (ed.) Prihodnost slovenskega podeželja. Novo mesto: Dolenjska založba, str. 31-45.

Jarvis, P. (ed.) (2001). The Age of Learning. Education and the Knowledge Society. London: Kogan Page.

Putnam, R. (2000). Bowling Alone. New York: Simon \& Schuster.

Rifkin, J. (2001). L' era dell'accesso. Milano: Mondadori.

Ritzer, G. (1999). Mekdonaldizacija društva. Istraživanje mijenjajučih karaktera suvremenog društva. Zagreb: Naklada Jesenski i Turk.

Sennett, R. (2001). L'uomo flessibile. Milano: Feltrinelli.

Steiner, C., Perry. P. (1999). Achieving Emotional Literacy. A Personal Program to Increase Your Emotional Intelligence. London: Bloomsbury.

Telban, B. (2000). Andaypa. Maribor: Založba Obzorja. Weber, M. (1988). Protestantska etika in duh kapitalizma. Ljubljana: ŠKUC in FF.

Zupan, N. Ograjenšek, J. (1999). Ravnanje s človeškimi viri. V: Prašnikar, J. (ed.) Poprivatizacijsko obnašanje slovenskih podjetij. Ljubljana: Gospodarski vestnik. 